\title{
THE SUPREME COURT AND RECENT SCHOOL DESEGREGATION CASES: THE ROLE OF SOCIAL SCIENCE IN A PERIOD OF JUDICIAL RETRENCHMENT
}

\author{
WILLIAM L. TAYLOR* \\ INTRODUCTION
}

In nearly a quarter of a century of Supreme Court decisionmaking on public school desegregation there have been ebbs and flows. While the Court has not deviated from the principle announced in Brown $v$. Board of Education ${ }^{1}$ that deliberate segregation of public schools violates the Constitution, its actions since 1954 have alternately sped and slowed the achievement of a remedy.

Perhaps the key to the Court's posture toward desegregation at any time lies in public opinion and the attitudes of the Congress and the President. Interestingly, however, the Court often appears to be slightly out of sync with shifts in the more political branches of government.

After a long period of relative inactivity following the second Brown decision $^{2}$ the Court responded affirmatively to the enactment of the Civil Rights Act of 1964 and the vigorous enforcement actions of the Johnson administration. In 1968, in Green v. School Board of New Kent County, ${ }^{3}$ the Court declared that the test of any remedy was its effectiveness in "disestablishing stateimposed segregation,"4 and in 1971, in Swann v. Charlotte-Mecklenburg Board of Education, ${ }^{5}$ the Court validated the use of busing for school desegregation, thus helping to bring sweeping changes to the South. Two years later in Keyes

\footnotetext{
* Director, Center for National Policy Review, and Adjunct Professor of Law, Catholic University of America School of Law. The author is attorney or of counsel to the plaintiffs in several of the current school desegregation cases, including Evans v. Buchanan (Wilmington, Delaware), Arthur v. Nyquist (Buffalo, New York), and United States v. Board of School Commissioners (Indianapolis, Indiana).

1. 347 U.S. 483 (1954).

2. 349 U.S. 294 (1955). This period was characterized by massive resistance to desegregation in the old South, which arose after President Eisenhower and Congress failed to provide support for the Brown decision. The Court's reluctance to intervene in any but the most egregious cases of defiance of the law (see, e.g., Cooper v. Aaron, 358 U.S. 1 (1958)) is widely regarded as attributable to the lack of support in Congress and the Executive branch. See, e.g., Read, Judicial Evolution of the Law of School Integration Since Brown v. Board of Education, 39 LAw \& Contemp. Prob., Winter 1975, at 7, 12.

3. Green v. School Bd., 391 U.S. 430 (1968).

4. 391 U.S. at 439.

5. Swann v. Charlotte-Mecklenburg Bd. of Educ., 402 U.S. 1 (1971).
} 
v. School District No. I (the Denver case), the Court set down rules which made it clear that many school districts in the North and West could be held accountable for practices which resulted in segregation of the public schools. ${ }^{7}$ Yet the period during which these landmark decisions were made began in 1968, when Lyndon Johnson was preparing to leave office and the pro-civilrights mood of the sixties was beginning to dissipate. It ended in 1973, long after the Nixon administration had begun its assault on school desegregation, and as Congress was showing clear signs of rethinking the commitment to desegregation it had made in the 1964 law.

In 1974 the Court began a retrenchment, from which it has not yet emerged, that appeared to be responsive to the drumbeat of criticism from the Administration and Congress. During this period the Court has decided cases dealing with several important issues: (a) the standard for proving the existence of a constitutional violation in a district where segregation was not mandated by law before 1954; (b) the standard for determining the scope of a remedy once a violation has been proved; (c) the circumstances that may warrant further intervention by a court after the implementation of a remedy; (d) the standards for ascertaining whether interdistrict relief is justified; and (e) the circumstances under which it is appropriate for a court to order compensatory education as an adjunct to a school desegregation remedy.

The purpose of this article is to analyze the Court's handling of these issues in its post-1973 decisions. My basic thesis, contrary to the beliefs expressed by many commentators, ${ }^{8}$ is that the Court has not repudiated either directly or by implication any doctrine that it had adopted before 1973 to define constitutional violations or determine remedies. Rather, the majority has exhibited a reluctance to extend previously announced legal principles to claims for new remedies (e.g., to claims for interdistrict desegregation) and has used various braking devices, such as the requirement that lower court judges make more careful and detailed findings, to slow the progress of desegregation. While the difference between renouncing a doctrine and inhibiting its application in particular cases may seem small, it is nonetheless important. At a minimum, the Court has retained sufficient flexibility to accelerate desegregation again without being subject to the just accusation that it is ready today to renounce principles that only yesterday it regarded as fundamental.

The post-1973 cases are also interesting for what they suggest about the ill-defined role of social science evidence in school desegregation cases. In the

6. 413 U.S. 189 (1973).

7. A fuller review of the law from Brown until 1975 may be found in Levin \& Moise, School Desegregation Litigation in the Seventies and the Use of Social Science Evidence: Annotated Guide, 39 LAw \& Contemp. Prob., Winter 1975, at 50.

8. See, e.g., Yudof, School Desegregation: Legal Realism, Reasoned Elaboration, and Social Science Research in the Supreme Court, 42 Law \& Contemp. Prob., Autumn 1978, at 57. 
long-standing debate about the basis of the Brown decision, ${ }^{9}$ I cast my vote with those who argue that the gist of the legal wrong was the racial classification in segregation statutes and its massive racial insult to black people. ${ }^{10}$ Under this view, the sociological evidence of harm to children in segregated settings that the Court cited in footnote eleven was not an important element of the decision but lagniappe added by the Court, which hoped to enhance public acceptance of the decision by suggesting that the magnitude of the remedy was justified by the damage that segregation inflicted on defenseless children. But recent decisions suggest that social science evidence of another kind may be important in proving violations of the law. In the 1974 Milliken $v$. Bradley decision ${ }^{11}$ (Milliken I), in which the Court barred an interdistrict remedy for Detroit's segregated schools, the opinions of several members of the Court betray underlying beliefs (a) that the segregated conditions in most metropolitan areas are caused less by discriminatory practices of government than by a web of sociological and economic factors and (b) that progress made under court decisions and laws adopted during the 1960s has provided mobility for minorities that may render further judicial intervention unnecessary. Social science evidence on these questions, both inside and outside the courtroom, may have an impact on the context in which the Justices approach future cases-that is, on the perception of social conditions that enables them to reconcile a decision such as Milliken $l$ with their understanding of the dictates of the Constitution. ${ }^{12}$

While social science evidence has not played a major role in court findings of constitutional violations, it has been a more important factor at the remedy stages, where the equitable powers of courts ordinarily afford them a good deal of flexibility in shaping relief. ${ }^{13}$ However, by applying mechanistic legal formulations even at that stage, recent decisions of the Supreme Court, notably Dayton, ${ }^{14}$ appear to have limited a court's flexibility in using social science research findings and educational expertise to frame a remedy. Nonetheless, in the 1977 Milliken $v$. Bradley decision ${ }^{15}$ (Milliken II) the Court put its imprimatur on the notion that various forms of compensatory education may be indispensable adjuncts of desegregation, and thereby opened a whole new area for creative research by social scientists and educational experts.

9. See, e.g., Cahn, Jurisprudence, 30 N.Y.U. L. Rev. 150 (1955); W. Workman, The Case for тне South 26, 30, 197 (1960); Kalven, The Quest for the Middle Range: Empirical Inquiry and Legal Policy, in Law in a Changing America 56, 66 (G. Hazard ed. 1968).

10. See, e.g., Black, The Lawfulness of the Segregation Decisions, 69 YALE L.J. 421 (1960).

11. 418 U.S. 717 (1974). See text accompanying notes 61-68, 80-81 infra.

12. But see Yudof, supra note 8 , at 57.

13. See Levin \& Moise, supra note 7, at 80-88; Taylor, Benjes, \& Wright, School Desegregation and the Courts, Soc. Pol'y., Jan.-Feb. 1976, at 32.

14. Dayton Bd. of Educ. v. Brinkman, 433 U.S. 406 (1977). See text accompanying notes 32-42 infra.

15. Milliken v. Bradley, 433 U.S. 267 (1977). See text accompanying notes 99-106 infra. 


\section{The Standard for Proving a Constitutional Violation}

The basic standard for proving the existence of a constitutional violation in Northern and Western school systems (i.e., systems in states where racially dual systems were not mandated by statute in 1954) was articulated in Keyes $v$. School District No. $1,{ }^{16}$ the first Northern school case decided by the Supreme Court. To prove a violation of the equal protection clause of the fourteenth amendment, the Court said, plaintiffs must prove that government officials engaged in deliberate discrimination, i.e., "a current condition of segregation resulting from intentional state action." 17 Applying this standard, the Court approved lower court findings that the Denever school board had engaged in a policy of deliberate racial segregation in a substantial part of its school system, e.g., by selecting sites for new schools in residential areas that were highly segregated. ${ }^{18}$ The Court went further, however, and held that such practices in a substantial part of the district were sufficient to establish a prima facie case that the entire system was unlawfully segregated and needed a districtwide remedy, either on the presumption that the intentional segregative acts were not confined to a part of the school system ${ }^{19}$ or on the presumption that intentional segregative acts in a part of the school system had a "profound reciprocal effect" on the rest of the school system. ${ }^{20}$ Thus the burden was shifted to the school authorities to prove that "segregative intent was not among the factors that motivated their actions" in the remaining part of the school district. ${ }^{21}$

Some lower courts framed the standard in terms similar to the tort principle that a person is responsible for the natural consequences of his actions. Thus, in several cases the existence of segregative intent or purpose was presumed from school board actions that had the "natural, probable, and foreseeable result" of increasing or perpetuating public school segregation. ${ }^{22}$

In two recent decisions not involving school systems ${ }^{23}$ the Supreme Court

16. 413 U.S. 189 (1973).

17. Id. at 205. The Court distinguished de jure segregation, which is clearly unconstitutional, from de facto segregation, which is not. "[T]he differentiating factor between de jure segregation and so-called de facto segregation . . . is purpose or intent to segregate." Id. at 208.

18. Id. at $198-201$.

19. Id. at 207-08.

20. Id. at $201-03$.

21. Id. at 210 .

22. E.g., Oliver v. Michigan State Bd. of Educ., 508 F.2d 178, 181-82 (6th Cir. 1974). Accord, United States v. School Dist., 521 F.2d 530, 535 (8th Cir. 1975); Hart v. Community School Bd., 512 F.2d 37, 50 (2d Cir. 1975); Texas Educ. Agency v. United States, 532 F.2d 380, 388 (5th Cir. 1976). See discussion at note 43 infra.

23. Washington v. Davis, 426 U.S. 229 (1976) (public employment); Village of Arlington Heights v. Metropolitan Hous. Dev. Corp., 429 U.S. 252 (1977) (housing and zoning). 
stated that official action would not be held unconstitutional because it had a racially discriminatory effect unless that effect could be traced ultimately to a racially discriminatory purpose. ${ }^{24}$ The Court also indicated that it would require lower courts to make more specific findings of deliberate discriminatory intent, although there need not always be direct evidence. ${ }^{25}$

While these decisions refocused attention on Northern school desegregation, they do not appear to have impaired the principle of the Keyes decision. Both opinions embraced Keyes and did not foreclose the use of circumstantial evidence in determining intent. In Arlington Heights the Court said that " $\mathrm{t}] \mathrm{he}$ impact of the official action ... may provide an important starting point" in the ascertainment of intent. ${ }^{26}$ What is required, then, is "a sensitive inquiry into such circumstantial and direct evidence of intent as may be available." The Court suggested several factors that might be examined:

The historical background of the decision is one evidentiary source, particularly if it reveals a series of official actions taken for invidious purposes . . . . The specific sequence of events leading up to the challenged decision also may shed some light on the decisionmaker's purposes ....

The legislative or administrative history may be highly relevant, especially where there are contemporary statements by members of the decisionmaking body, minutes of its meetings, or reports. ${ }^{27}$

The Court also emphasized that the plaintiff need not "prove that the challenged action rested solely on racially discriminatory purposes." 28 The existence of nonracial factors that may explain the challenged action does not necessarily negate a finding of racial intent, for "[r]arely can it be said that the legislature or administrative body operating under a broad mandate made a decision motivated solely by a single concern, or even that a particular purpose was the 'dominant' or 'primary' one." 29 There need only be proof that a discriminatory purpose was one motivating factor in the decision. ${ }^{\mathbf{3 0}}$

24. 426 U.S. at 240 . In Washington $v$. Davis the plaintiffs were blacks who had applied for positions as police of ficers in the District of Columbia and had been rejected after failing a written exam. They brought suit against the District, charging that the test, which excluded a disproportionately high number of black applicants, was discriminatory and violated the equal protection component of the due process clause of the fifth amendment. The Supreme Court found no indications of discriminatory purpose in the District's administration of the test.

25. Id. " $[\mathrm{A}] \mathrm{n}$ invidious discriminatory purpose may often be inferred from the totality of the relevant facts ...."Id. at 242.

26. 429 U.S. at 266 . The Village of Arlington Heights had denied a rezoning petition by a contractor who had sought to build a racially integrated low- and moderate-income housing project. The contractor had brought suit declaring that the denial was in violation of the equal protection clause of the fourteenth amendment and was racially motivated. The Supreme Court held that the plaintiff was required to prove that racially discriminatory intent was a motivating factor in the village's decision.

27. Id. at 267-68.

28. Id. at 265 (emphasis added).

29. Id.

30. Id, at 265-66. 
While Davis and Arlington Heights both spoke approvingly of the Keyes decision, civil rights advocates were understandably apprehensive of how the decisions would be applied when the Supreme Court took on another Northern school desegregation case. The test came in a 1977 case $^{31}$ in which a reluctant district court judge, acting under instructions from the court of appeals, ${ }^{32}$ had approved a thoroughgoing plan for desegregation of all public schools in the Dayton system. ${ }^{33}$

The district court had found three constitutional violations in the Dayton school system: (1) racially imbalanced schools, (2) the use of optionalattendance zones, allowing white high school students to transfer out of what would have been integrated schools, and (3) the recission by the school board of resolutions adopted but not yet implemented by the previous school board to provide for voluntary desegregation of these schools.$^{34}$ The court of appeals had hinted broadly that there might well have been other constitutional violations which the district judge had failed to include in his finding of a cumulative constitutional violation; ${ }^{35}$ but the court of appeals had found it unnecessary to consider these since, in its view, the findings already made by the district court were sufficient to support the districtwide plan. ${ }^{36}$ This decision was vacated by a unanimous Supreme Court, and the case was remanded for new findings and conclusions about violations in light of Washington $v$. Davis and Arlington Heights. ${ }^{37}$

The Supreme Court's Dayton decision does not appear to have deviated from the Keyes principle or even to have added a gloss on Keyes as explicated in the Washington v. Davis and Arlington Heights decisons. Rather, Dayton applied the standard of those cases to a set of facts that failed to meet the standard.

The Supreme Court's conclusion that two of the three alleged violations would not meet the standard of Keyes, Washington $v$. Davis, and Arlington Heights was not disingenuous. A holding that racial imbalance per se, whatever its causes, constituted a constitutional violation would have obliterated the

31. In 1976 the Supreme Court vacated the Fifth Circuit's judgment in the Austin school desegregation case, remanding it for reconsideration in light of Washington $v$. Davis-a signal, if somewhat cryptic, that courts must find specific racially discriminatory intent on the part of school officials who adopt neighborhood school assignment plans, rather than merely showing racially discriminatory effects of such plans. Austin Indep. School Dist. v. United States, 429 U.S. 990 (1976). The applicability of the Washington $v$. Davis and Arlington Heights standard to school desegregation cases was not fully articulated until the following year, however, in the Dayton case. Dayton Board of Education v. Brinkman, 433 U.S. 406 (1977).

32. Brinkman v. Gilligan, 518 F.2d 853 (6th Cir. 1975).

33. The plan called for the transportation of some 15,000 students to bring all schools within 15 percent of the $48-52$ black-white population ratio.

34. The findings of the district court are discussed in detail in the circuit court's opinion. 503 F.2d 684, 693-97 (6th Cir. 1974).

35. 503 F.2d at $697-703$.

36. Brinkman v. Gilligan, 539 F.2d 1082 (6th Cir. 1976).

37. 433 U.S. 406,419 (1977). 
very distinction between de jure (intentional) and de facto (adventitious) segregation that Keyes sought to make. ${ }^{38}$ As for the rescission of a desegregation plan that had not yet been implemented, the Supreme Court agreed with the court of appeals that if the school board had not been under a constitutional duty to remedy segregation in the first place because it had not engaged in deliberate acts of discrimination, "the rescission of the initial [voluntary] action in and of itself cannot be a constitutional violation." 39 In other words, the voluntary plan and the rescission were deemed to cancel each other out, leaving the school board in the same situation as one which had not acted but had no constitutional duty to act. ${ }^{40}$

As for the optional-attendance zones, the Supreme Court assumed that they were a violation-a view consistent with Keyes, Washington $v$. Davis, and Arlington Heights. But the Court noted that the zones affected only a few high schools, and concluded that this violation, standing alone, would not warrant a systemwide remedy that included elementary as well as high schools. ${ }^{41}$

Since the court of appeals had made no determination about other violations (relating to staff assignment, school construction, and other matters apparently in the record), the Supreme Court sent the case back to the district court with instructions to make new findings and conclusions about violations. The Court noted that supplementation of the record would be necessary in any event to deal with "the disparity between the evidence of constitutional violations and the sweeping remedy finally decreed." 42

In sum, the Court in Dayton did not depart from its previous definition of a constitutional violation. ${ }^{43}$ It merely found that two of the alleged violations

38. 413 U.S. at 208 .

39. 433 U.S. at 414 (quoting Brinkman v. Gilligan, 503 F.2d 684, 697 (6th Cir. 1974)).

40. If the school board had gone beyond a simple cancellation of its plan and changed the procedures for obtaining school desegregation, the constitutional issue would have been different. For example, legislation that requires civil rights laws, ordinances, or regulations to be approved by referendum or by amendment to the state constitution may offend the equal protection clause by treating racial problems differently from related governmental interests. See Reitman v. Mulkey, 387 U.S. 369 (1967); Hunter v. Erickson, 393, U.S. 385 (1969). Even where minorities may have no initial right to a fair-housing ordinance or a school desegregation plan, government may not take action which makes it substantially more difficult for minorities to achieve their goals through the political process than for others.

41. 433 U.S. at 413-18.

42. Id. at 419. On remand the district court dismissed the case, saying that the plaintiffs had failed to prove the necessary discriminatory intent and that the school board's actions were not per se violations of the plaintiff's constitutional rights. 446 F. Supp. 1232 (1977). On appeal, the Sixth Circuit found the trial court's findings to be "clearly erroneous," made its own findings of fact and conclusions of law (Brinkman v. Gilligan, 583 F.2d 243) and reinstated the district desegregation plan. (6th Cir. 1978).

43. The question has been raised whether the Dayton decision can be interpreted as requiring plaintiffs to bear a heavier burden of proof of intentional segregation than in the past. The response of several post-Dayton lower court decisions indicates that this is not the case. Following the Supreme Court's remand of the Austin case, 429 U.S. 990 (1976), the Fifth Circuit articulated what it took to be the appropriate standard for determining intent: 
did not meet the standard and that the third finding-concerning the use of optional zones in a segregative way-although probably a violation of the consituation, was not sufficient to support a sweeping remedy.

\section{The Standard for Determining the Scope of the Remedy After a Violation Has Been Found}

Beyond defining the standard for ascertaining whether a constitutional violation exists, Keyes provided guidance for lower courts in taking the next steps. The opinion stated that "a finding of intentionally segregative school board actions in a meaningful portion of a school system . . . creates a presumption that other segregated schooling within the system is not adventitious." 44 This common-sense presumption was designed to aid courts in ascertaining the scope of the violation, and thus the appropriate scope of the remedy. ${ }^{45}$ A school board has an opportunity to offer evidence to rebut the

\footnotetext{
When the official actions challenged as discriminatory include acts and decisions that do not have a firm basis in well accepted and historically sound nondiscriminatory social policy, discriminatory intent may be inferred from the fact that those acts had foreseeable discriminatory consequences. As a practical matter, in school desegregation cases we can envision few official actions, other than the decision to use a neighborhood school policy for student assignment, that would not be subject to the "natural foreseeable consequences" rule. The presumption is especially probative in assessing the official intent behind such affirmative school board decisions as those concerning school locations, the construction and renovation of schools, the closing of schools, the drawing of student attendance zones, and the assignment of faculty and staff.
}

United States v. Texas Educ. Agency, 564 F.2d 162, 168-69 (5th Cir. 1977) (footnotes omitted). The court noted, however, that deliberate discriminatory intent could not "be inferred solely from the school board's use of a neighborhood school policy for student assignment." Id. at 169 (emphasis added). See note 21 supra and accompanying text for discussion of pre-Dayton and Arlington Heights cases.

Similarly, on remand of the Milwaukee case, Brennan v. Armstrong, 433 U.S. 672 (1977), the district court stated, in clarifying and expanding its previous findings of intentional discriminatory action on the part of school authorities:

[A] presumption of discriminatory intent arises from a showing that increased or continued racial segregation was the foreseeable result of official action or inaction that did not further avowed governmental policies or that ignored less segregative options which were equally consistent with governmental policies.

Armstrong v. O'Connell, 451 F. Supp. 817, 824 (E.D. Wis., 1978). See also Arthur v. Nyquist, 573 F.2d 134, 142-43, (2d Cir. 1978); N.A.A.C.P. v. Lansing Bd. of Educ., 559 F.2d 1042, 1046-48 (6th Cir. 1977), cert. denied, 434 U.S. 997 (1977); United States v. School Dist. 565 F.2d 127, 128 (8th Cir. 1977), cert. denied, 434 U.S. 1064 (1978); Reed v. Rhodes, 455 F. Supp. 569 (N.D. Ohio 1978); Berry v. School Dist., 442 F. Supp. 1280, 1291-94 (W.D. Mich. 1977). See also Note, Reading the Mind of the School Board: Segregative Intent and the De Facto/De Jure Distinction, 86 YALE L. J. 317 (1976).

44. 413 U.S. at 208 (emphasis added).

45. The Supreme Court viewed the presumption as appropriate for two reasons: First, constitutional violations are likely to have reciprocal effects on schools other than those directly affected by the discriminatory actions: "[C]ommon sense dictates the conclusion that racially in- 
presumption in ways that are outlined in some detail in Keyes, but if it fails to do so, "proof of state-imposed segregation in a substantial portion of the district will suffice to support a finding of the existence of a dual system." 46 Once a dual system is found to exist, a systemwide remedy is required because the board has a duty to desegregate "root and branch." 47

In Dayton, then, since the only valid lower court finding pertained to the use of optional-attendance zones for a few high schools, there was no constitutional violation in a meaningful or substantial part of the school system. Thus, there simply were not adequate findings to trigger the Keyes presumption, and the Supreme Court was justified in concluding that "the District Court's findings of constitutional violations did not, under our cases, suffice to justify the [systemwide] remedy imposed." 48 Thus, nothing in Dayton threatens any impairment of the Keyes presumption where violations in a meaningful portion of a system are shown.

While Dayton does not appear to have changed the basic principles governing Northern desegregation cases, it does require district judges to make specific findings before imposing a systemwide remedy. The concluding section of the Court's opinion states:

The duty ... is to first determine whether there was any action in the conduct of the business of the school board which was intended to, and did in fact, discriminate against minority pupils, teachers or staff . . . If such violations are found, the District Court in the first instance ... must determine how much incremental segregative effect these violations had on the racial distribution of the Dayton school population as presently constituted, when that condition is compared to what it would have been in the absence of such constitutional violations. The remedy must be designed to redress that difference, and only if there has been a systemwide impact may there be a systemwide remedy. Keyes, supra at $213 .{ }^{49}$

The Court clearly attaches importance to this section of its opinion. Two days after the Dayton opinion, the Court remanded for reconsideration school desegregation cases concerning Omaha ${ }^{50}$ and Milwaukee. ${ }^{51}$ In each case the Court noted that the lower courts had not met the Dayton requirement that

\footnotetext{
spired school board actions have an impact beyond the particular schools that are the subjects of those actions." 413 U.S. at 203.

Second, proof of intent to segregate in one area of a district is relevant to the causes of segregation in another area under the jurisdiction of the same school authority: "Plainly, a finding of intentional segregation as to a portion of a school system is not devoid of probative value in assessing the school authorities' intent with respect to other parts of the same school system." Id. at 207.

46. Id. at 203 (emphasis added).

47. Id. at 213 (quoting Green v. School Bd., 391 U.S. 430, 438 (1968)).

48. 433 U.S. at 414.

49. Id. at 420 .

50. School Dist. v. United States, 433 U.S. 667 (1977) (per curiam).

51. Brennan v. Armstrong, 433 U.S. 672 (1977) (per curiam).
} 
they determine how much of the segregation was attributable to the unconstitutional actions of school authorities.

But the practical significance of this passage is a bit harder to ascertain. It would be a challenge worthy of the most dedicated team of social scientists to assess what the condition of segregation in a community "would have been in the absence of . . . constitutional violations." ${ }^{52}$ Yet that is what the Court has said is needed in order to determine the proper scope of a remedy.

In practical terms, the effect of the Dayton requirement is likely to depend on who has the burden of proof in a particular case. If, on the one hand, plaintiffs must prove that no segregation would have existed in their community in the absence of a constitutional violation, they are likely to fail in that task, and school desegregation remedies may become more and more piecemeal. If, on the other hand, defendants must prove that segregation would exist in the community even in the absence of a constitutional violation, they are likely to fail, and systemwide remedies will be the rule rather than the exception.

While the Court did not explicitly relate the requirement outlined in Dayton to the presumption outlined in Keyes, a relationship between the two was implied: in Dayton the Court not only failed to overturn Keyes but also cited Keyes, as we have seen, on the crucial subject of systemwide remedies. ${ }^{53}$ Keyes ruled that once a constitutional violation had been found in a "substantial portion" of a school district, the burden of proof was shifted to the defendants to rebut the presumption that segregation in the remaining portion of the district was either a direct product or a reciprocal effect of deliberate segregative actions. ${ }^{54}$ If that burden cannot be met, then the plaintiffs are entitled to "a finding by the trial court of the existence of a dual [school] system," ${ }^{55}$ and a systemwide remedy is required.

Thus, once plaintiffs have made a showing that deliberately discriminatory practices caused segregation in a substantial part of the district, it will fall to the defendants to show that segregation in the remaining part would have occurred even in the absence of these practices.

This will surely not be an easy task. The defendants' burden might be met, for example, by showing, as suggested in Keyes, that the "natural boundaries" within the district divided it into "separate, identifiable and unrelated units"56

52. Note 48 supra.

53. Note 48 supra. But see Kanner, From Denver to Dayton: The Development of a Theory of Equal Protection Remedies, 72 N.W.U. L. REv. 382, 404-05 (1977) for the argument that the Keyes presumptions have been "abandoned." See also Yudof, supra note 8 , at 57.

54. Note 45 supra.

55. 413 U.S. at 203.

56. Id. 
(e.g., that the district was divided into two parts by the Grand Canyon), ${ }^{57}$ so that segregative actions taken in one part may not have had a reciprocal effect on schools in another part. But the burden would probably not be satisfied by the claim frequently made by school boards that segregation is due to a variety of demographic, sociological, and economic factors and that the segregation in their communities is not essentially different from the segregation in Detroit, Cleveland, Philadelphia, and other cities. If the burden is on a school board, its assertion that the school system's segregated pattern is like that of other communities is unavailing, since the segregation in those communities may also be attributable to constitutional violations. One would have to find or construct an ideal community untainted by any constitutional violations to use as a measuring rod.

While the Supreme Court acknowledged in Dayton that ascertaining the incremental segregative effect of constitutional violations would be a "difficult task," ${ }^{8}$ the Keyes presumption makes the task manageable for plaintiffs. If plaintiffs have proved intentional segregation in a meaningful part of a system, they will ordinarily be in a position to obtain systemwide relief under the Keyes presumption. ${ }^{\mathbf{5 9}}$

Nevertheless, the direction taken by the Court in the Dayton case seems unfortunate. Ordinarily, federal courts, as courts of equity, have considerable discretion in fashioning a remedy for a wrong. In school desegregation cases courts have been able to take into account evidence that a plan involving all rather than some schools in a district may be more stable and acceptable to the community because it distributes the white and black school population fairly evenly and does not leave ready havens for white flight. ${ }^{60}$ Courts have

57. In Keyes a six-lane highway was not considered to be a barrier dividing the district into "separate, identifiable and unrelated units." Id. at 204-05.

58. 433 U.S. at 420.

59. Several lower courts have addressed the problem raised by the passage in Dayton in which district courts are admonished to determine how much "incremental segregative effect" intentionally discriminatory governmental actions have had on the current racial composition of schools. Id. at 420 . These courts have concluded that the Keyes allocation of the burden of proof still applies. The Austin court, for example, after noting that "[a]ssessing the incremental segregative impact of a school board's discriminatory actions and policies is not an easy task," United States v. Texas Educ. Agency, 564 F.2d 162, 175 (5th Cir. 1977), cited Keyes as support for its determination that "[t]he burden of demonstrating that the residential concentration of minorities in East Austin is unrelated to the [school district's] . . . segregative school policies is to be shouldered by the school board." Id. at 175. The court of appeals noted further that, in assessing the extent of the impact of discriminatory school board actions, the district court "should keep in mind the Supreme Court's statement in Keyes that 'racially inspired school board actions have an impact beyond the particular schools that are the subjects of those actions." Id. quoting Keyes, 413 U.S. at 203.

See also Brinkman v. Gilligan, 583 F.2d 243 (6th Cir. 1978); Evans v. Buchanan, 582 F.2d 750 (3d Cir., 1978) (en banc); Penick v. Columbus Bd. of Educ., 583 F.2d 787 (6th Cir. 1978)

60. See, e.g., Augustus v. School Bd., 361 F. Supp. 383, 389 (N.D. Fla. 1973). In Wright v. City 
also considered, at least implicitly, how well a particular desegregation plan accords with the findings of social scientists on educational issues. ${ }^{61}$

While Dayton does not exclude these considerations, it moves toward a more legalistic and mechanistic set of guidelines for remedies. It will be ironic if those who resist busing remedies on the grounds that government ought to be concerned with education as a whole rather than integration alone succeed in having the courts exclude educational factors from consideration in desegregation remedies.

\section{III}

\section{Metropolitan-Area Remedies}

In Milliken v. Bradley (Milliken $)^{62}$ the Supreme Court for the first time handed down a decision delineating the circumstances under which school district lines may be disregarded in remedies for unconstitutionally segregated school systems. By a narrow 5-4 vote the Court reversed a lower court decision requiring a metropolitan-area desegregation plan for Detroit, which had been found to have an unconstitutional dual school system. ${ }^{63}$ But in doing so the Court outlined when such a remedy might be appropriate. In essence, the majority said that the prerequisite for interdistrict relief was not only "a current condition of segregation resulting from intentional state action" "64 but also a violation that was of an interdistrict character. Thus, in the Detroit case the scope of the remedy exceeded "the nature and extent of the constitutional violation," 65 which was confined to Detroit. The circumstances that may in future cases give rise to interdistrict relief can be summarized as follows:

1. "[T]here has been a constitutional violation within one district that produces a significant segregative effect in another district"; ${ }^{66}$ or

2. "district lines have been deliberately drawn on the basis of race"67 (majority opinion) or state officials "contributed to the separation

Council, 407 U.S. 451 (1972), the Supreme Court, in barring a city from withdrawing from an existing county school district while the system was under a court order to desegregate, noted the possibility of white flight from the county to the city as one of the factors that would impede achievement of a remedy that met constitutional standards.

61. See, e.g., Hobson v. Hansen, 269 F. Supp. 401 (D.D.C. 1967), aff'd sub nom. Smuck v. Hobson, 408 F.2d 175 (D.C. Cir. 1969); Davis v. School Dist., 309 F. Supp. 734 (E.D. Mich. 1970), aff'd, 443 F.2d 573 (6th Cir.), cert. denied, 404 U.S. 913 (1971).

62. 418 U.S. 717 (1974).

63. The finding that the Detroit school district was de jure segregated was not questioned by the Supreme Court. Id. at 738, n. 18.

64. Keyes v. School Dist. No. 1, 413 U.S. 189, 205 (1973).

65. 418 U.S. at 744 .

66. Id. at 745 .

67. Id. 
of the races by drawing or redrawing school district lines"68 (concurring opinion of Mr. Justice Stewart); or

3. state officials "had contributed to the separation of the races ... by purposeful racially discriminatory use of state housing or zoning laws"69 (concurring opinion of Mr. Justice Stewart).

Since 1974 the two major cases presenting claims for interdistrict relief -one involving the Wilmington, Delaware school district and the other the school district of Indianapolis-have focused in large part on the second ground: the manipulation of district lines in ways that contributed to segregation. In Evans v. Buchanan ${ }^{70}$ a three-judge federal district court had held that a 1969 Delaware statute generally authorizing the state board of education to reorganize and consolidate school districts unconstitutionally excluded Wilmington. The background of that law included the facts that the Wilmington school district was more than two-thirds black when the law was enacted, that there were unremedied violations within Wilmington, and that almost half of all black students in the state lived in Wilmington. The Supreme Court summarily affirmed this decision without opinion. ${ }^{71}$ The lower court then reiterated its findings of interdistrict violations (which included housing violations as well) and held that a school desegregation plan encompassing most of the metropolitan area was required to remedy the violation. ${ }^{72}$ The Court of Appeals for the Third Circuit affirmed, ${ }^{73}$ and the Supreme Court again refused to review the case, ${ }^{74}$ virtually assuring that a metropolitan-area plan would go into effect.

In the Indianapolis case $\mathrm{e}^{75}$ the issue of interdistrict relief was raised after the United States had proved extensive intradistrict violations. The Court of Appeals for the Seventh Circuit eventually held that the creation of a form of metropolitan-area government in Indianapolis and Marion County without a like reestablishment of school boundaries constituted the kind of interdistrict violation contemplated by Milliken $I$. It also held that the concentration of public housing within the city excluded black pupils from the suburbs and contributed to interdistrict segregation. ${ }^{76}$ Early in 1977 , however, the Su-

68. Id. at 755 (Stewart, J., concurring).

69. Id.

70. 393 F. Supp. 428 (D. Del. 1975).

71. Buchanan v. Evans, 423 U.S. 963 (1975).

72. Evans v. Buchanan, 416 F. Supp. 328 (D. Del. 1976).

73. Evans v. Buchanan, 555 F.2d 373 (3d Cir. 1977).

74. Cert. denied, 98 S. Ct. 235 (1977). In 1978, the District Court approved an extensive metropolitan plan and the court of appeals has recently approved the remedy. Evans $v$. Buchanan, 582 F.2d 750 (3rd Cir. 1978).

75. United States v. Board of School Comm'rs, 541 F.2d 1211 (7th Cir. 1976).

76. Id. at 1223 . 
preme Court vacated the judgment and remanded the case for reconsideration in light of Arlington Heights and Washington $v$. Davis ${ }^{77}$ thus raising the question of the degree of racial intent that is needed to prove an interdistrict violation. ${ }^{78}$ Nevertheless, the Wilmington and Indianapolis cases show that where special circumstances such as the manipulation of school district boundaries can be proved, metropolitan-area remedies may be obtained.

The more important question, both for the future of metropolitan-area remedies and in posing a challenge to social scientists, is what it will take to establish "purposeful racially discriminatory use of state housing or zoning laws" which "contributed to the separation of the races."79 The departure point for such a determination must be the concurring opinion of Mr. Justice Stewart in Milliken 1, where these phrases appear. Justice Stewart, the only member of the majority to assert that deliberately discriminatory state housing policies may give rise to a school desegregation remedy, ${ }^{\mathbf{8 0}}$ was unpersuaded that such policies accounted for the segregated character of the Detroit metropolitan area. ${ }^{81}$ Stewart wrote:

77. Board of School Comm'rs v. Buckley, 429 U.S. 1068 (1977).

78. Note that in Milliken $I$ Mr. Justice Stewart, the swing vote, formulated the standard on boundary manipulation in a way that appears to require less of a showing of racial intent than the other four Justices in the majority. 418 U.S. at 753-56 (Stewart, J., concurring).

In later remanding the Indianapolis case to the district court, the Seventh Circuit noted that the constitutional violation might be entirely confined to the district but could yield an interdistrict remedy if it had an effect beyond the district's borders. United States v. Board of School Comm'rs, 573 F.2d 400, 405 n.4 (7th Cir. 1978). Addressing the state's failure to extend school district boundaries when it expanded the government of Indianapolis to include all of Marion County, the court noted that much of the necessary test articulated in Milliken $I$ for sustaining an interdistrict remedy was fulfilled: there had been state action-indeed, action "contrary to the State's traditional policy," $i d$. at 407 , and there were clearly discernible interdistrict effects. Id. Therefore, to justify its interdistrict remedy, the court of appeals said, the district court needed only to find that the assembly's failure to extend the school district boundaries was motivated by a discriminatory purpose. Id. at $\mathbf{4 0 8}$. The Seventh Circuit also pointed out that state housing violations could trigger an interdistrict school remedy if discrimination led directly to segregated housing patterns (e.g., if decisions to locate low-income housing inside "old" Indianapolis exacerbated white flight) and "state action, at whatever level, by either direct or indirect action, initiated, supported, or contributed to these practices and the resulting housing patterns and population shifts." Id. at 409. Moreover, although state action need not have been the sole cause of the segregated housing patterns, "it must have had a significant rather than a de minimis effect." Id.

79. Note 69 supra.

80. The question of other nonschool governmental agencies which may have contributed to the pattern of residential segregation was expressly reserved for future decision by the Court in Swann v. Charlotte-Mecklenburg County Bd. of Educ., 402 U.S. 1, 23 (1971). For technical reasons the majority in Milliken $I$ did not reach this issue. See note 81 infra.

Justice Powell, however (joined by the Chief Justice and Justice Rehnquist), in a 1976 opinion concurring in the Court's order remanding the Austin case, noted that "discrimination in housing-whether public or private-cannot be attributed to school authorities." Austin Indep. School Dist. v. United States, 429 U.S. 990, 994 (1976) (emphasis added).

81. Chief Justice Burger, for the majority, said that the case did not present any question of possible state housing violations because the court of appeals had not relied on such violations, although a record had been made in the district court, 418 U.S. at 728 n.7. Justice Stewart, however, said that "[n]o record has been made ... showing that the racial composition of the 
It is this essential fact of a predominantly Negro school population in Detroit -caused by unknown and perhaps unknowable factors such as in-migration, birth rates, economic changes, or cumulative acts of private racial fears-that accounts for the "growing core of Negro schools," a "core" that has grown to include virtually the entire city. The Constitution simply does not allow federal courts to attempt to change that situation unless and until it is shown that the State, or its political subdivisions, have contributed to cause the situation to exist. ${ }^{82}$

One may infer that Mr. Justice Stewart meant that the growth in the black population of many central cities was the result of black in-migration and high black birth rates, while the decline in the white population of the central cities and the increase in the white population of the suburbs was the result of economic changes (including the relocation of industry) and cumulative acts of private racial fears (white flight). But this analysis leaves at least one important gap: it fails to explain why black people are not found in significant numbers in the suburban sections of metropolitan areas. On this issue $\mathrm{Mr}$. Justice Stewart apparently professes no knowledge, although he noted that it has not been proved that racially discriminatory government policies played a significant role.

Elsewhere 1 have described the kinds of evidence used in metropolitan cases to demonstrate that government has played a major role in containing black people in the central cities ${ }^{83}$ Plaintiffs have sought to show that historically, government at all levels helped to create and maintain racially segregated neighborhoods, particularly during the period when federal aid spurred the growth of suburbs. They have also introduced evidence that recent government policies favoring fair housing have not been sufficient to eradicate the effects of past discrimination and that even today there are instances in which government continues to promote or tolerate segregation. Through demographic analyses plaintiffs have tried to establish that the continuing high degree of racial separation in residential patterns is not due in large measure to economic factors or private preference but to discrimination in which government is implicated. ${ }^{84}$

Evidence of this kind runs counter to the apparent assumption by $\mathrm{Mr}$. Justice Stewart and other Justices that socioeconomic influences account for segregation in metropolitan areas, ${ }^{85}$ that major barriers to black mobility have

Detroit school population or that residential patterns within Detroit and in the surrounding areas were in any significant measure caused by governmental activity." 418 U.S. at 756 n.2.

82. Id. at $756 \mathrm{n} .2$ (emphasis added).

83. See Taylor, The Supreme Court and Urban Reality: A Tactical Analysis of Milliken v. Bradley, 21 Wayne L. Rev. 751 (1975).

84. Plaintiffs in such cases have often relied on the kinds of research described in Farley, Residential Segregation and Its Implications for School Integration, 39 LAW \& Contemp. Prob., Winter 1975 , at 164 .

85. See Mr. Justice Powell's concurring opinion in Keyes, 413 U.S. at 236. 
been removed by the legislation and litigation of the $1960 \mathrm{~s}$, and that drastic judicial intervention (in the form of interdistrict school relief) is rarely if ever necessary. But the need for research on these issues has hardly been exhausted. The question for social scientists as well as lawyers is whether the causes of black concentration in inner cities are indeed "unknown and perhaps unknowable." ${ }^{86}$ If they are not, the challenge is to develop research and analysis that will construct a more accurate picture of the causes of racial separation in urban areas and, in the process, a more persuasive case for metropolitan interdistrict remedies.

\section{The Duration of Desegregation Remedies}

In Swann v. Charlotte-Mecklenburg Board of Education ${ }^{87}$ the Supreme Court briefly addressed the question whether school authorities have a continuing duty, after a court-ordered desegregation plan has been put into effect, to correct racial imbalance:

It does not follow that communities served by [unitary] systems will remain demographically stable, for in a growing, mobile society, few will do so. Neither school authorities nor district courts are constitutionally required to make year-by-year adjustments of the racial composition of student bodies once the affirmative duty to desegregate has been accomplished and racial discrimination is eliminated from the system. This does not mean that federal courts are without power to deal with future problems; but in the absence of a showing that either school authorities or some other agency of the state has deliberately attempted to fix or alter demographic patterns to affect the composition of the schools, further intervention by a district court should not be necessary. ${ }^{88}$

The first opportunity to apply these general principles came in Pasadena City Board of Education v. Spangler, ${ }^{89}$ but the result was not particularly illuminating. In 1970 a federal district court, having found de jure segregation, had ordered the implementation of a desegregation plan which stipulated that minority students should not constitute a majority of the students at any Pasadena school. ${ }^{90}$ Soon after the implementation of the plan some schools had deviated from this principle because of population shifts. In 1974 the school board had asked the court to terminate its jurisdiction over the case or to give the school board authority to substitute a plan which might result in much less desegregation. The lower court had refused, principally on the

86. Note 82 supra.

87. 402 U.S. 1 (1971).

88. Id. at $31-32$.

89. 427 U.S. 424 (1976).

90. 311 F. Supp. 501, 505 (C.D. Cal. 1970). 
grounds that since the decree there had almost continuously been a number of schools that were not in accord with the "no majority of any minority" standard. The court had also implied that the board would be required to meet this standard for the foreseeable future. ${ }^{91}$ The court of appeals approved the district court's action, while disapproving its suggestion that future year-by-year reassignments were appropriate to maintain the "no majority of any minority" standard. ${ }^{92}$ The Supreme Court vacated the decision and sent it back for further proceedings. ${ }^{93}$

The gist of the Supreme Court's opinion was that a court could not require pupil reassignments to maintain a racial balance some four or five years after the orginal decree unless the original decree had been violated or further deliberate segregative practices had occurred. The Court said, "[H]aving once implemented a racially neutral attendance pattern in order to remedy the perceived constitutional violations .. . the District Court had fully performed its function of providing the appropriate remedy for previous racially discriminatory attendance patterns." 94

The decision is as important for what it does not say as for what it does. The Court does not hold that it would have been inappropriate for the district court to require in its initial decree in 1970 that the school board reassign students each year for several years to prevent resegregation. For the Court to have said this would have meant that a system that had been in violation of the law for years could become a unitary school system in a single moment without continuing court supervision. The difficulty in Pasadena was that in its 1970 decree the district court had not required yearly reassignments. In 1974, therefore, it was not in a position to base continuing supervision on a violation of its 1970 order. Thus, even after Pasadena lower courts can require school boards to reassign students for a period of years to prevent resegregation. ${ }^{\mathbf{9 5}}$

Another question not addressed by Pasadena was under what circumstances resegregation would be deemed the product of government attempts "to fix or alter demographic patterns." ${ }^{96}$ While some useful research on white flight and resegregation has been done, ${ }^{97}$ additional empirical studies may help illuminate this issue when the Court faces it again.

\footnotetext{
91. 375 F. Supp. 1304, 1309 (C.D. Cal. 1974).

92. 519 F.2d 430 (9th Cir. 1975).

93. 427 U.S. 424 (1976).

94. Id. at 436-37.

95. See, e.g., United States v. Seminole County School Dist., 553 F.2d 992, 994-95 \& n.7 (5th Cir. 1977); Haycraft v. Board of Educ., 560 F.2d 755, 756 (6th Cir. 1977).

96. Note 88 supra.

97. See, e.g., Symposium on School Desegregation and White Flight (C. G. Orfield ed. 1975) (co-sponsored by the Center for National Policy Review, Catholic University of America School of Law, and the Center for Civil Rights, University of Notre Dame); Rossell, School Desegregation and Community Social Change, 42 Law \& Contemp. Prob., Summer 1978, at 133.
} 


\section{Remedial Programs as an Adjunct to Desegregation}

After the Supreme Court overturned a metropolitan-artea desegregation plan for Detroit in Milliken $I^{\mathbf{9 8}}$ the case was returned to the district court for formulation and implementation of an intradistrict plan. Several measures were proposed by the Detroit board of education and by the plaintiffs for inclusion in the desegregation plan, among them: (1) in-service training for teachers and administrators; (2) new guidance and counseling programs; (3) revised testing programs; and (4) a remedial reading and communicationskills program. The district court found that the current testing and counseling programs, for which replacements had been proposed, were "infected with a discriminatory bias." 99 It also found, after hearing expert testimony, that the other two proposed programs were essential to successful desegregation efforts. ${ }^{100}$ The state, which was required by the district court to pay part of the costs of the desegregation plan, appealed on the ground that the remedy must be commensurate with the constitutional violation. Since the constitutional violation was racially discriminatory pupil assignments, the state argued, the court's decree must be limited to remedying the unconstitutional pupil assignments. ${ }^{101}$ But both the Court of Appeals for the Sixth Circuit ${ }^{102}$ and the Supreme Court, in Milliken II, agreed with the district court. ${ }^{103}$

The Supreme Court's opinion in Milliken II is intriguing. It considered the question whether remedial programs were necessary adjuncts to desegregation in the context of its previous admonitions on the appropriate scope of a remedy, which said that the purpose of a remedy was to cure the "condition that offends the Constitution" and to restore the victims of discrimination to the position they would have occupied in the absence of discrimination. ${ }^{104}$ In the Court's view, this meant that a desegregation plan must on occasion deal with matters other than pupil assignment because "[d]iscriminatory student assignment policies can themselves manifest and breed other inequalities built into a dual system founded on racial discrimination." 105

98. 418 U.S. 717 (1974).

99. Bradley v. Milliken, 402 F. Supp. 1096, 1118 (E.D. Mich. 1975). The Supreme Court characterized this as a finding that these programs "were infected with the discriminatory bias of a segregated school system." Milliken v. Bradley, 433 U.S. 267, 275 (1977).

100. Bradley v. Milliken, 402 F. Supp. at 1138-39.

101. 540 F.2d 229, 236 (6th Cir. 1976). The State's second objection to the relief granted was that under the eleventh amendment it could not be compelled to pay for the ancillary relief ordered. Id. at 242.

102. Id. at 246.

103. 433 U.S. 267 (1977).

104. Id. at 282 .

105. Id. at 283 . 
The question remained whether the specific programs mandated were tailored to remedy the consequences of the constitutional violation that had been found. The Court concluded that they were:

Children who have been thus educationally and culturally set apart from the larger community will inevitably acquire habits of speech, conduct and attitudes reflecting their cultural isolation. They are likely to acquire speech habits, for example, which vary from the environment in which they must ultimately function and compete if they are to enter and be a part of that community. ... The root condition ... . must be treated by special training at the hands of teachers prepared for that task. ${ }^{106}$

While compensatory programs as adjunts to desegregation remedies are not an uncommom part of lower court orders, this was the first time the Supreme Court had articulated the rationale for such programs. The rationale may be viewed in some respects as unduly narrow, focusing as it does on the "deprivation" of minority students and not on the practices and attitudes that pervade segregated school systems and that may have a continuing impact on all students if not corrected. Nevertheless, given the fact that the Court has been reluctant to mandate the expenditure or redistribution of funds for educational purposes, ${ }^{107}$ Milliken II may provide the basis for channeling assistance to students for identified needs. ${ }^{108}$ While the record in Milliken II consisted largely of expert testimony, the decision is an invitation to creative social scientists to engage in more thorough research. Such efforts may identify conditions that are associated with racial and cultural isolation and may assist in the development of programs that can serve as useful adjuncts to desegregation orders.

\section{Conclusion}

Several weeks after the Supreme Court decided Milliken I, one Justice of the Court, Byron White, introduced a fellow Justice, Potter Stewart, at a Yale Law School reunion by describing his role as "the flywheel" of the Court. A flywheel, Justice White explained, is a heavy wheel which opposes or modifies by its inertia any fluctuation in the speed of the machinery with which it revolves. Justice White noted that Justice Stewart sometimes slowed and some-

106. Id. at $287-88$.

107. See San Antonio Indep. School Dist. v. Rodriguez, 411 U.S. 1 (1973).

108. Several post-Milliken II cases have raised this issue. In the Wilmington metropolitan case the district court ordered a comprehensive educational program, ancillary to the pupil reassignment plan, which included in-service teacher training, a reading and communication-skills program, a review of teaching materials that would eliminate any racial bias, new counseling and guidance programs, nondiscriminatory guidelines for new construction and school closings, a human-relations program, a code of rights and responsibilities for student discipline, and reassignment of staff and faculty. Evans v. Buchanan, 582 F.2d 750 (3d Cir. 1978) (en banc), aff'd, 447 F. Supp. 982, 1015-17 (D. Dcl. 1978). The state was ordered to bear the costs of the remedial educational program. Id. at 55 . 
times sped the machinery of the Court. Although no Justice on the Court today participated in the 1954 decision, throughout the years the Court has maintained a fairly consistent commitment to the principles espoused in Brown. The variations have been largely in the speed of the Court's machinery in implementing the decision.

What accounts for these variations? The late Justice Robert Jackson once observed that in some areas of the law results are "likely to depend on the imperatives of events and contemporary imponderables rather than on abstract theories of law." 109 In school desegregation cases, where decisions often require major social change, the Court, keenly aware of the need for public acceptance, has often looked to the other branches of the federal government for support. In the 1970s, as in the 50s, the greatest imponderable in the legal struggle to secure equality of opportunity is Presidential leadership. No factor is likely to be as decisive for what may be expected from the Court in the coming years as whether President Carter decides ultimately to grasp the nettle of leadership.

At the same time, Court decisions are only rarely unalloyed demonstrations of Mr. Dooley's preaching that the Supreme Court follows the election returns. ${ }^{10}$ Decisions reflecting a public mood hostile or favorable to the rights of minorities are almost always accompanied by the articulation of views of societal conditions which, whether truly or conveniently held, enable the Justices to reconcile their decisions with their understanding of the Constitution. Thus, decisions of the late nineteenth century upholding discrimination and segregation were at least in part products of the view that the black had "emerged from slavery, and by the aid of beneficent legislation [had] . . . shaken off the inseparable concomitants of that state."111 While Brown did not rest on social science evidence of harm to black children, the decision cannot be separated from a view that the state-mandated order of segregation was a crucial instrument in denying opportunity to black people.

So if in Milliken $I$ there are echoes of the nineteenth-century belief that courts have done enough to balance the scales, social scientists may have an important role in describing more realistically an urban society in which race still stands as a barrier to opportunity. Finally, despite the mechanistic approach to remedy in Dayton, broad scope still exists for creative efforts by educators and social scientists. They continue to face the challenge of developing desegregation plans that offer the best prospects for stability and acceptance and that realize the promise of Brown by providing opportunity and mobility for all children.

109. Youngstown Sheet \& Tube Co. v. Sawyer, 343 U.S. 579, 637 (1952) (Jackson, J., concurring).

110. "[N]o matter whether th' Constitution follows th' flag or not, th' Supreme Court follows th' iliction returns." F. P. Dunne, Mr. Dooley at His Best 77 (1938).

111. Civil Rights Cases, 109 U.S. 3, 25 (1883). 